\title{
The cytokine interleukin-26 as a biomarker in pediatric asthma
}

\author{
Jon R. Konradsen ${ }^{1,2,3}$, Björn Nordlund ${ }^{2,3,4}$, Bettina Levänen ${ }^{5}$, Gunilla Hedlin 2,3,4 and Anders Linden 5,6*
}

\begin{abstract}
In this pilot study, we examined associations between local interleukin (IL)-26, disease severity and biomarkers of Th2-mediated inflammation in a well-defined cohort of pediatric patients (14 years median age, $41 \%$ females) with controlled $(n=28)$ or uncontrolled $(n=48)$ asthma. Sputum IL-26 protein concentrations (ELISA) reflected disease control in patients without local (low exhaled nitric oxide) or systemic (low blood eosinophils) signs of eosinophilic inflammation. Moreover, sputum-IL-26 concentrations correlated with those of blood neutrophils. Our study indicates that IL-26 is a potential biomarker of disease severity in pediatric asthma without signs of Th2-mediated inflammation.
\end{abstract}

Keywords: Asthma, Children, Eosinophil, FENO, IL-26, Neutrophil, Sputum

\section{Introduction}

Dear Editor,

Up to $20 \%$ of children with severe asthma have no signs of eosinophilic inflammation [1] and these pediatric patients respond poorly to inhaled corticosteroids and anti-IgE, pharmacotherapy that was originally designed to target severe Th2-mediated inflammation [2]. For these patients, there is a need to increase the understanding of the immunological events underlying the disease, to establish biomarkers for improved diagnosis and monitoring, as well as to identify potential targets for therapy [2].

The presumed Th17 cytokine interleukin (IL)-26 is an intriguing member of the IL-10 family; one that is involved in several chronic inflammatory disorders and can exert both pro- and anti-inflammatory actions, depending upon the setting [3]. However, there is currently no conclusive information on the involvement of IL-26 in the pathogenesis of asthma or any other chronic inflammatory airway disorder [4]. A recent study on healthy human subjects indicates that this cytokine is produced by Th17 cells, as well as by other leukocytes, and that IL-26 contributes to the mobilization of neutrophils in the airways during activation of pulmonary host defense by endotoxin [5]. Given these facts, we

\footnotetext{
* Correspondence: anders.linden@ki.se

${ }^{5}$ Unit for Lung and Airway Research, Institute of Environmental Medicine,

Karolinska Institutet, PO Box 210, SE-17177 Stockholm, Sweden

${ }^{6}$ Lung Allergy Clinic, Karolinska University Hospital Solna, SE-171 76

Stockholm, Sweden

Full list of author information is available at the end of the article
}

hypothesized that local IL-26 is associated with severe disease in pediatric asthma lacking signs of eosinophilic inflammation.

\section{Methods}

To address our hypothesis, we utilized data from a previously well-characterized cohort of school-age children ( $n=76)$ with severe uncontrolled (uncontrolled) or persistent controlled (controlled) asthma [6]. Briefly, uncontrolled asthma was diagnosed in a child with reduced asthma control despite treatment with high doses of inhaled corticosteroids ( $\geq 800 \mu \mathrm{g}$ budesonide equivalent per $24 \mathrm{~h}$ ), whereas controlled asthma was defined as children having an acceptable asthma control with a low to moderate daily dose of inhaled corticosteroids (100 $400 \mu \mathrm{g}$ budesonide equivalent per $24 \mathrm{~h}$ ). The patients were recruited as previously described [6], after approval by the Regional Ethics Review Committee in Stockholm (Stockholm) and after informed consent from each patient or parent, in full accordance with the Helsinki declaration.

We quantified IL-26 protein concentrations in the airways in relation to asthma severity, blood eosinophils (B-EOS), exhaled nitric oxide (FENO) and blood neutrophils (B-NEUTRO). Specifically, we utilized cell-free samples of induced sputum [7] for the measurement of IL-26 protein concentrations $(\mathrm{ng} / \mathrm{mL})$ with ELISA (Cusabio Biotech ${ }^{\circ}$ [5]. 


\section{Results}

Among our included pediatric patients, the median age (range) was 13.7 years (7-19), with $41 \%$ being females. The 48 patients with uncontrolled asthma had a reduced score on the asthma control test (17 versus 23, $p<0.001)$, and a lower $\mathrm{FEV}_{1}$ (82\% versus $90 \%$ predicted, $p=0.04$ ) despite receiving a higher dose of inhaled corticosteroids $(800 \mu \mathrm{g}$ versus $320 \mu \mathrm{g}$ of budesonide, $p<0.001$ ) compared to the 28 children with controlled asthma. In addition, the children with uncontrolled asthma had higher concentrations of B-EOS (0.4 versus $0.2, p=0.02)$ and B-NEUTRO (3.2 versus. 2.6, $p=0.03)$ than those with controlled asthma.

In the entire cohort, the median FENO levels were 18.3 p.p.b and the median B-EOS concentration was $0.3 \times 10^{9} / \mathrm{L}$. These median values were used to categorize children into groups with high and low levels of these biomarkers of Th2-mediated inflammation, independently of the predefined severity classification.

Among children with low concentrations B-EOS $\left(\leq 0.3 * 10^{9} / \mathrm{L}\right)$, we observed higher concentrations of IL26 in uncontrolled compared to controlled asthma (Fig. 1a \& Table 1). Furthermore, we found a corresponding association between asthma control and IL-26 concentrations among children with low levels of FENO (Fig. 1b \& Table 1). A trend towards an association between asthma control and IL-26 concentrations in the entire cohort was observed, but it was not statistically significant (Table 1). Furthermore, when investigating children with high concentrations of B-EOS and high levels of FENO, the difference in distribution of IL-26 between children with uncontrolled and controlled asthma was less pronounced (Table 1).

Finally, we found a weak but statistically significant correlation (the Pearson test: $r=0.27, p=0.018, n=76$ ) between the concentrations of B-NEUTRO and IL-26 in the entire cohort of pediatric patients with asthma and this correlation tended to be stronger in the patients with low levels of FENO $(r=0.35, p=0.036, n=36)$. There was no evident correlation between IL-26 concentrations and age, gender, height or dose of inhaled corticosteroids.

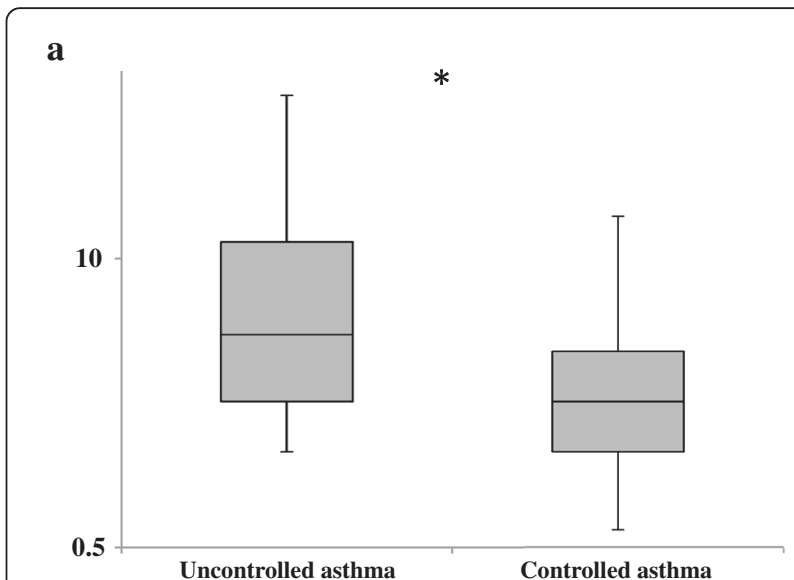

b

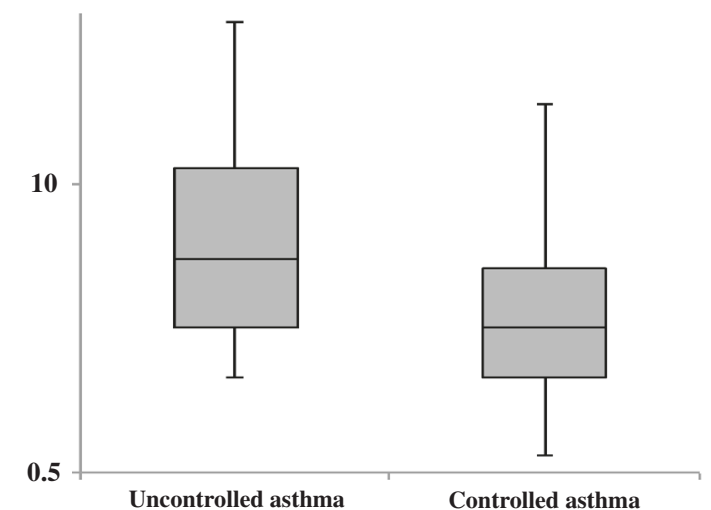

Fig. 1 Median concentrations (logarithmically transformed) of IL-26 $(\mathrm{ng} / \mathrm{mL})$ in induced sputum from children with uncontrolled versus controlled asthma and a low concentrations of eosinophils in blood $\left(\leq 0.3 \times 10^{9} / \mathrm{L}\right)$ or $\mathbf{b}$ low levels of exhaled nitric oxide ( $\leq 18.3$ p.p.b)

\section{Discussion}

Our study is the first to associate local IL-26 protein concentrations in the airways with a certain clinical phenotype of pediatric asthma. The fact that IL-26 protein concentrations are increased in sputum from pediatric patients with uncontrolled asthma but without signs of Th2-mediated inflammation forwards IL-26 as a potential, novel biomarker of disease severity in this

Table 1 Interleukin-26 in the airways of children with uncontrolled versus controlled asthma

\begin{tabular}{|c|c|c|c|c|c|}
\hline & $\begin{array}{l}\text { IL-26 (ng/ml) } \\
\text { Uncontrolled asthma }\end{array}$ & $n$ & $\begin{array}{l}\mathrm{IL}-26(\mathrm{ng} / \mathrm{ml}) \\
\text { Controlled asthma }\end{array}$ & $n$ & $p$-value* \\
\hline All patients & $4.4(1.9-14)$ & 48 & $2.4(1.3-4.5)$ & 28 & 0.077 \\
\hline Low B-EOS $\left(\leq 0.3 \times 10^{9} / \mathrm{L}\right)$ & $4.6(2.3-13)$ & 27 & $2.3(1.3-4.5)$ & 22 & $0.038^{*}$ \\
\hline High B-EOS $\left(>0.3 \times 10^{9} / \mathrm{L}\right)$ & $4.1(1.7-16)$ & 21 & $2.9(1-31)$ & 5 & 0.61 \\
\hline Low FENO (s 18.3 p.p.b.) & $4.1(2.2-16)$ & 23 & $2.0(1.2-3.6)$ & 13 & 0.055 \\
\hline High FENO (>18.3 p.p.b) & $5.0(1.8-13)$ & 25 & $2.7(1.4-24)$ & 15 & 0.54 \\
\hline
\end{tabular}

Footnotes. The IL-26 concentrations are presented as medians with inter-quartile ranges

The median values in the entire cohort of the respective biomarker were used to define the cut-off between high and low levels of the various biomarkers. $B$-EOS blood eosinophils, FENO the fraction of nitric oxide in exhaled air, in parts per billion. *Independent samples, analyzed by Mann-Whitney U-test (SPSS ${ }^{\circledR}$ version 20$)$ 
phenotype of asthma. These findings are also supported by a positive correlation between local IL-26 and systemic neutrophils (ie. B-NEUTRO); a correlation in line with a mechanistic link between IL-26 and the mobilization of neutrophils as recently indicated in human airways [5, 8].

One of the effects of treatment with inhaled corticosteroid is an inhibition of the production of Th2 cytokines such as IL-4 and IL-5, which subsequently attenuate eosinophilic recruitment and the release of toxic granulae proteins [9]. The observed clinical effects are an improvement of symptoms and pulmonary function and a reduced rate of asthma exacerbations [10]. It is widely accepted that increased concentrations of blood eosinophils and high levels of FENO indicate systemic and local eosinophilic inflammation, respectively $[11,12]$. In addition, it is known that low levels of these established biomarkers are associated with a reduced sensitivity to inhaled steroids [13, 14]. Given that our findings are compatible with an increase in local IL-26 being associated with inflammation not mediated by Th2-related mechanisms; this observation forwards the clinically relevant question whether IL-26 is also linked to low sensitivity to inhaled steroids in pediatric patients with non-allergic asthma? New studies are required to address this possibility; a possibility that has implications for the estimated $13 \%$ of children with severe asthma displaying excess neutrophil mobilization [1].

Even though the size of our study material was modest, a particular strength of our current analysis is the standardized and detailed characterization of each individual patient; making it possible to identify various subgroups within this cohort. We think that this facilitated the discovery that IL-26 provides a potentially clinically relevant signal in patients without signs of local or systemic eosinophilic inflammation.

\section{Conclusion}

Our pilot study demonstrates that local IL-26 bears potential as a biomarker of disease severity in a clinical phenotype of pediatric asthma that is perpetuated by other than Th2-related mechanisms.

\section{Abbreviations}

B-EOS: blood eosinophils; B-NEUTRO: blood neutrophils; FENO: the fraction of nitric oxide in exhaled air; $\mathrm{FEV}_{1}$ : forced expiratory volume during $1 \mathrm{~s}$; IL: interleukin; Th: T helper.

\section{Competing interests}

The authors declare that they have no competing interests.

\section{Authors' contributions}

The author contributions were as follows: The conception and design of the study involved JRK, GH and AL; the data analysis and interpretation involved: JRK, BN, BL, GH and ALN; and, finally, the drafting of the manuscript included: JRK, GH and AL. All authors read and approved the final manuscript.

\section{Acknowledgements}

For statistical considerations, Max Vikström, Ph.D., Unit for Cardiovascular Epidemiology, Institute of Environmental Medicine, Karolinska Institutet, was consulted. Funding for this study was obtained from the Centre for Allergy Research at Karolinska Institutet, the Freemason Child House Foundation in Stockholm, the Konsul Th. C. Bergh's Foundation, the Swedish Asthma and Allergy Association's Research Foundation, the Pediatric Research Foundation of Astrid Lindgren Children's Hospital, and the Swedish Heart-Lung Foundation.

\section{Author details}

${ }^{1}$ Clinical Immunology and Allergy Unit, Department of Medicine Solna, Karolinska Institutet and Karolinska University Hospital, SE-171 76 Stockholm, Sweden. ${ }^{2}$ Centre for Allergy Research, Karolinska Institutet, SE-171 77 Stockholm, Sweden. ${ }^{3}$ Astrid Lindgren Children's Hospital, Karolinska University Hospital Solna, SE-171 76 Stockholm, Sweden. ${ }^{4}$ Department of Women's and Children's Health, Karolinska Institutet, SE-171 76 Stockholm, Sweden. ${ }^{5}$ Unit for Lung and Airway Research, Institute of Environmental Medicine, Karolinska Institutet, PO Box 210, SE-17177 Stockholm, Sweden. ${ }^{6}$ Lung Allergy Clinic, Karolinska University Hospital Solna, SE-171 76 Stockholm, Sweden.

Received: 9 January 2016 Accepted: 23 March 2016

Published online: 31 March 2016

\section{References}

1. Bossley CJ, Fleming L, Gupta A, Regamey N, Frith J, Oates T, Tsartsali L, Lloyd CM, Bush A, Saglani S. Pediatric severe asthma is characterized by eosinophilia and remodeling without $\mathrm{T}(\mathrm{H}) 2$ cytokines. J Allergy Clin Immunol. 2012;129(4):974-82. e13.

2. Chung KF, Wenzel SE, Brozek JL, Bush A, Castro M, Sterk PJ, Adcock IM, Bateman ED, Bel EH, Bleecker ER, Boulet LP, Brightling C, Chanez P, Dahlen SE, Djukanovic R, Frey U, Gaga M, Gibson P, Hamid Q, Jajour NN, Mauad T, Sorkness RL, Teague WG. International ERS/ATS guidelines on definition, evaluation and treatment of severe asthma. Eur Respir $\rfloor$ 2014;43(2):343-73.

3. Tengvall S, Che KF, Linden A. Interleukin-26: An emerging player in host defense and inflammation. J Innate Immun. 2016;8(1):15-22.

4. Pene J, Chevalier S, Preisser L, Venereau E, Guilleux MH, Ghannam S, Moles JP, Danger Y, Ravon E, Lesaux S, Yssel H, Gascan H. Chronically inflamed human tissues are infiltrated by highly differentiated Th17 lymphocytes. J Immunol. 2008;180(11):7423-30.

5. Che KF, Tengvall S, Levanen B, Silverpil E, Smith ME, Awad M, Vikstrom M, Palmberg L, Qvarfordt I, Skold M, Linden A. Interleukin-26 in antibacterial host defense of human lungs. Effects on neutrophil mobilization. Am J Respir Crit Care Med. 2014;190(9):1022-31.

6. Konradsen JR, Nordlund B, Lidegran M, Pedroletti C, Gronlund H, van Hage M, Dahlen B, Hedlin G. Problematic severe asthma: a proposed approach to identifying children who are severely resistant to therapy. Pediatr Allergy Immunol. 2011;22(1 Pt 1):9-18.

7. Pizzichini E, Pizzichini MM, Efthimiadis A, Evans S, Morris MM, Squillace D, Gleich GJ, Dolovich J, Hargreave FE. Indices of airway inflammation in induced sputum: reproducibility and validity of cell and fluid-phase measurements. Am J Respir Crit Care Med. 1996;154(2 Pt 1):308-17.

8. Griffiths KL, Khader SA. Bringing in the cavalry: IL-26 mediates neutrophil recruitment to the lungs. Am J Respir Crit Care Med. 2014;190(10):1079-80.

9. Barnes PJ, Pedersen S. Efficacy and safety of inhaled corticosteroids in asthma. Report of a workshop held in Eze, France, October 1992. Am Rev Respir Dis. 1993;148(4 Pt 2):S1-26.

10. Papadopoulos NG, Arakawa H, Carlsen KH, Custovic A, Gern J, Lemanske R, Le Souef P, Makela M, Roberts G, Wong G, Zar H, Akdis CA, Bacharier LB, Baraldi E, van Bever HP, de Blic J, Boner A, Burks W, Casale TB, CastroRodriguez JA, Chen YZ, El-Gamal YM, Everard ML, Frischer T, Geller M, Gereda J, Goh DY, Guilbert TW, Hedlin G, Heymann PW, Hong SJ, Hossny EM, Huang JL, Jackson DJ, de Jongste JC, Kalayci O, Ait-Khaled N, Kling S, Kuna P, Lau S, Ledford DK, Lee SI, Liu AH, Lockey RF, Lodrup-Carlsen K, Lotvall J, Morikawa A, Nieto A, Paramesh H, Pawankar R, Pohunek P, Pongracic J, Price D, Robertson C, Rosario N, Rossenwasser LJ, Sly PD, Stein R, Stick S, Szefler S, Taussig LM, Valovirta E, Vichyanond P, Wallace D, Weinberg E, Wennergren G, Wildhaber J, Zeiger RS. International Consensus on (ICON) pediatric asthma. Allergy. 2012;67(8):976-97. 
11. Pavord ID, Bafadhel M. Exhaled nitric oxide and blood eosinophilia: independent markers of preventable risk. J Allergy Clin Immunol. 2013;132(4):828-9.

12. Konradsen JR, Skantz E, Nordlund B, Lidegran M, James A, Ono J, Ohta S, Izuhara K, Dahlen SE, Alving K, Hedlin G. Predicting asthma morbidity in children using proposed markers of Th2-type inflammation. Pediatr Allergy Immunol. 2015;26(8):772-9.

13. Alving KMA. Basic aspects of exhaled nitric oxide. Eur Respir Mon. 2010:49(1):1-31.

14. Taylor DR, Pijnenburg MW, Smith AD, De Jongste JC. Exhaled nitric oxide measurements: clinical application and interpretation. Thorax. 2006;61(9):817-27.

Submit your next manuscript to BioMed Central and we will help you at every step:

- We accept pre-submission inquiries

- Our selector tool helps you to find the most relevant journal

- We provide round the clock customer support

- Convenient online submission

- Thorough peer review

- Inclusion in PubMed and all major indexing services

- Maximum visibility for your research

Submit your manuscript at www.biomedcentral.com/submit
Biomed Central 